\title{
RELIGION AND RELIGIOUS LANGUAGE A RELIGIOUS SYMBOLISM FOR NONRELIGIOUS PURPOSES
}

\author{
Aminullah Elhady \\ State Institute for Islamic Studies (IAIN) Jember, Indonesia \\ aminelhady@yahoo.com
}

\begin{abstract}
Religion is a very important thing in the people's lives. They need religion because of their weaknesses and limitations to face something outside themselves. Their limitations, especially in spiritual and metaphysical aspects, hence the people search for references which are considered hits, it is the religion. The spirit of religion in the collective life is to create the beneficiaries for the adherents. But, the religious symbolism is no less important than religion in life, so that religious symbols are greatly needed by the people. Moreover, religious symbolism is sometimes treated more than to the religion itself. Maybe public passion towards religious symbols more powerful than passion towards religion itself. Because it's not uncommon religious symbols are used for a variety of interests outside the religious interests, for example economic interests, political interests, and so on.
\end{abstract}

Key words: religion, religious laguage, political interest, social conflict.

\begin{abstract}
Abstrak
Agama adalah hal yang sangat penting dalam kehidupan masyarakat. Mereka membutuhkan agama karena kelemahan dan keterbatasan mereka untuk menghadapi sesuatu di luar diri mereka. Keterbatasan mereka, terutama dalam aspek spiritual dan metafisis, maka orang-orang mencari referensi yang dianggap hits, itu adalah agama. Semangat agama dalam kehidupan kolektif adalah menciptakan para penerima manfaat bagi para penganutnya. Namun, simbolisme agama tidak kurang penting daripada agama dalam kehidupan, sehingga simbol-simbol agama sangat dibutuhkan oleh rakyat. Selain itu, simbolisme agama kadang-kadang diperlakukan lebih dari pada agama itu sendiri. Mungkin hasrat publik terhadap simbol-simbol agama lebih kuat daripada hasrat terhadap agama itu sendiri. Karena itu tidak jarang simbol-simbol agama digunakan untuk berbagai kepentingan di luar kepentingan agama, misalnya kepentingan ekonomi, kepentingan politik, dan sebagainya.
\end{abstract}

Kata kunci: agama, laguage religi, minat politik, konflik sosial.

\section{Intoduction}

Talking about the religious language, it cannot be separated from discourses on religion and language. Religion can be defined as a belief in God or gods to be worshiped and usually it is expressed in conduct and ritual or any specific system of belief, worship, etc. It is involving a code of ethics and values. The language is a means of communication and a means of thinking. As a means of communication, the language allows one to interact with each other verbally or written. Meanwhile, as a means of thinking, the language allows one to develop widely a variety of ideas. Through the ideas one can determine the basic views on issues he faces. ${ }^{1}$

${ }^{1}$ Achmad Syahid, Lanaguage, Education, and Religion, (Jakarta: Logos, 2002). p. 143. 
Religion is usually regarded as one of the greatest issues for individuals or society, because it is a sacred for their lives. So, everyone knows what religion is. It is a relationship that humans consider themselves to have had with God. It is also a way of living or an ethical system. ${ }^{2}$ It is also motivated by the people's awareness as a set of transcendental values. In the empirical level, religion is also one of the most sensitive aspects in the social life, and therefore it is not uncommon because of a religious sensitivity it may evoke an irrational jealousy. Although what one defends and promotes as a "religion" is sometimes not clearly perceived by the defenders.

In the history of human life, what called a religion which is due to the greatness and the glory as a transcendental work, often used as a medium for various purposes, not as an "interest" that emerged from the religious teachings, but for the benefits of persons or groups of defenders. There are people who want to get a profit by "selling" the religion or religious issues. Likewise, the meanings signaled by the Quran (Al-Baqarah, 2: 41; Al-Maidah, 5: 44), " and barter not My revelation for a little gain", ${ }^{3}$ so that the people not to sell the verses of God in the name of religion for a very short-term interests, namely worldly interests.

\section{The Symbols}

A symbol is an object that represents, stands for, or suggests an idea, visual image, belief, action, or material entity. Symbols take the form of words, sounds, gestures, or visual images and are used to convey ideas and beliefs.

In this life symbols are so important for individuals, groups, and institutions. For the people of religions, image of crescent or star-crescent shows the symbol of Islam or Muslim community. As well as the Christian cross is the symbol of Christianity or Christian community. The symbols are signs of honor and dignity. But, many of the people are satisfied with the symbols without understanding the meaning and the substance. If we only pay attention to the symbols without regarding to the meaning, then we may be fooled. If a dome on the top of a building in the Muslim countries is often regarded as a mosque, there is a dome on the large building in Los Angeles and it is visible from a distance, but the building is not a mosque but Shrine Building belonging to the Jewish community there. ${ }^{4}$

In history of Pagan faith, as mentioned in the Quran, Ibrahim was sentenced to burn because of beheading statues they worshiped, and that was an insult to the religious symbol. It seems that all religions have introduced religious symbols to its adherents. Perhaps the simple reason that the symbol is a sign to express something marked.

2 Albanese, Catherine, America Religions \& Religion, (Santa Barbara: Thomson, 2007). p. 2.

${ }^{3}$ Muhammad Pickthall, The Meaning of the Glorious Quran: Text and Explanatory Translation, (Karachi: Idaratul Quran, 1980), p. 108.

4 Syafiq Mughni, Behind the Symbols: Understanding Religious Message with the Spirit of Progress, (Surabaya: Hikmah Press, 2011), p. 3-4. 
In everyday life, symbol or mark is an instrument that served as a medium of communication. As well as in the social life, the religious communication also uses symbols as a medium. Among the religious symbols those are so strong binding adherents such as temple or house of worship and holy books.

In this contemporary life, religious symbols are still required and treated as something that sometimes exceed greater than the religion greatness itself. Empirically, it can be found within the framework of political, economic, social, cultural, and other aspects of public life.

More specifically, the symbols of religion are not only used to attract public sympathy and support for constructive purposes, but also for the contrary. Therefore in the view of who does not look carefully and cautiously, religion is often judged to contain elements which, paradoxically, deliver the realization of peace and prosperity on the one hand and lead to a conflict and violence on the other hand. These are problems from time to time pervading religious communities. Is it true that the religion creates peace and conflict, or it arises from the religion followers hands?

This paper designed to deliver talks on the theme of "religion and violence", with descriptions of religious symbols in history, symbols of religion in the contemporary era in global and local scope, as well as a conflict and a violence colored both political and economic interests, or socio-cultural nuances and so by taking religious symbols.

\section{Religious Symbolism in the Past and the Present}

It is an illustration described here, that during the time of the Prophet religious symbols were also used although it was not stated whether or not. For example, in Hudaybia treaty between the Prophet of Islam and Suhail bin Amr from the Quraish tribe, the Prophet dictated the draft of agreement to be written by Ali ibn Abi Talib. The manuscript begins with the word "Bismillâh ar-Rahmân ar-Rahîm" (in the name of Allah, the Most Gracious and Merciful); during spelling the expression, Suhail interrupted by stating: "We do not know what arRahmân ar-Rahîm and, therefore replace it with what we know. Therefore write with the phrase Bismika Allâhumma (by your name, O God)". Over the objections of the Quraish leader, the Prophet asked Ali to obey it. The next thing that will be written by Ali on the Prophet's order is min Muhammad rasûlillâh (This statement comes from Muhammad the Messenger of Allah); during spelling this phrase the Quraish leader again interrupted saying: "If we know you as a 'messenger of God' of course we will follow you, therefore replace the last phrase with your name and the name of your father". Once again the Prophet did not mind with the Quraish request, then he asked Ali to write: min Muhammad ibn 'Abd Allah (from Muhammad son of Abdullah), and so on, as well as what cited by 
Munawir Sjadzali. ${ }^{5}$ The stories about this case can be found in some traditions, such as narrated by al-Bukhari, Muslim, Al-Tirmidhi and Ahmad. ${ }^{6}$

What stated above is an example that in the classical period there were religious symbols known, considered necessary, such as the name of Al-Rahman to God, and the word Rasul to state the position of Muhammad. The flexible attitude of the Prophet was impressive that although the symbols is necessary but not absolute.

In the subsequent history, religious symbols also appeared both with regard to political and social problems. In Islamic history, a state leader such as Caliph also at the same time also sat on the position as a religious leadership, so that called "Amir al-Mu'mineen" (leader of the believers). Even more, there was a statement that a caliph is the shadow of God on this earth (zhilâl Allâh fi al-ard). It indicates that the word Allah (God) which associated with the position of the Caliph was important for him to strengthen his position in the view of the religious people.

Through the history we also have known, that the book of Quran has been ever functioned as a symbol of peace in the event of a dispute or war between groups of Muslims. For example, when the war occured between the supporters of Muawiya and Ali's group, in an urgence condition Amr ibn As who led Muawiya's group lifted up the book of Quran as a symbol of peace invitation. Because of that symbol, Ali and a group of his supporters willed to stop the war to welcome the peace. ${ }^{7}$ Although should be considered that these efforts are part of strategy and tactics of war.

In the Islamic caliphate period until the last period under the Ottoman rule, a caliph is a symbol of religious leadership and unity of Muslims worldwide. Likewise contained in many faiths and religions, there are many examples of religious symbols for certain interests which can be found in history.

Symbols for some religions seem more assertive in theological nuances. We can see in the Christianity, how the statues of Jesus and Mary are placed and treated. Although theologically the Christians do not worship statues, but to facilitate the woshipers making transcendental communication, they consider that it is necessary to make the statues as medium of worship. Such the arguments actually have been raised by the idolaters in the past, as mentioned in the Quran (Al-Zumar, 39: 3), "Surely pure religion is for Allah only. And those who choose protecting friends beside Him (say): We worship them only that they may bring us near unto Allah". 8 They claimed that they did not worship idols but simply as a way to bring them to be near to God. So idols become the medium between them and God in the ritual activity.

${ }^{5}$ Munawir Sjadzali, Islam and Constitutions, (Jakarta: UI-Press. 2000), p. 17-19.

${ }^{6}$ Al-Maktaba al-Shamela, version 3.48. http:/ / www.shamela.ws

7 Philip Hitti, History of the Arabs, (London: Macmillan, 1970), p. 180-181.

8 Muhammad Pickthall, The Meaning of the Glorious Quran: Text and Explanatory Translation, (Karachi: Idaratul Quran, 1980), p. 493. 
In some parts of the world there are many problems arise with religious symbols. In the time of the 1979 Islamic Revolution in Iran, for example, the power of the people was raised by promoting religious symbols to overthrow the despotic power of Shah Reza. While Khomeini, a person who titled with Ayatollah and Ruhollah (a very high title, especially in the socio-theological perspective among the Shia followers), physically he was a very old man, besides he was in exile, first in Turkey, then in Iraq, and the last in France. ${ }^{9}$ But, with religious symbols attached to himself he was able to influence the people through recording his lectures and teachings.

In Indonesia, since ancient time, religious symbols have been used in many ways. The kings of Mataram, in addition held a political power also held a religious one as "the caliph of God and religion regulator". The Indonesian President Sukarno also has been dubbed the religious predicate as waliyyul amr (the Great Guardian).

Here we see that the religious symbolism has a power to influence the people and bring them to react seriously. Symbolism is important and needs to take care with the religious life, so that the steps in people's lives always in the framework of religious teachings. However, it is not impossible for elements of interest interfere by using a religious symbol to influence the people and direct them to reach the goals of interested parties.

\section{Religious Symbolism and Social Conflict}

When there is a view that religion has a potential to create conflicts in society, then here need to be discussed. The religion due to many people considered to play an important key in terms of the people's lives, namely as an integrative factor which can unite them, but on the other hand is regarded as a disintegrating factor. It is called the disintegrative factor because the religion itself has a potential to create a conflict, either because of the interpretation of the religion itself or deliberately undertaken by certain parties, in the name of religion or religious symbolism for a particular interest.

Theoretically humans are creatures in the highest degree compared with other creatures. But, according to the Koran, it could be the opposite in quality, become more abject than being despised, if the elements of amplifier (faith and good deeds) decline. Stated in the Holy Quran (Al-Tin, 95: 4-5): "Surely We created man of the best stature. Then we reduce him to the lowest of the low". ${ }^{10}$ The height of human being is partly supported by the soul and intellect. While as a form of being he classified as living beings (animal) like other living things, which require feeding, reproduction, protection, and so on, in the form of physical needs.

${ }_{9}^{9}$ Abrahamian, Radical Islam: The Iranian Mojahedin, (London: Tauris, 1989), p. 426.

10 Pickthall. The Meaning of the Quran. p. 721. 
A philosopher named Thomas Hobbes (1588-1679) once said that human is a homo homini lupus, or being predatory neighbor. Although the expression of the philosopher is not entirely appropriate, but there is empirical evidence that justifies the statement. Even if we take an analogy with a kind of animals that develop and move only by its instinct, perhaps there is no type of animal as a predator for animal like. Tiger the king of the jungle never encounter prey or kill another tiger. While often found in a systematic way (not based on instinct) a man try to kill another who is considered to be a bully or obstruction his life. If we find an animal has actual aggressive behavior, really it is just a defensive effort in order to survive.

Unlike animals, the humans have instincts and potential which may be intended for the benefit of themselves and also taking into account the benefit of the others. Yet, humans have instinct to dominate others.

The individual character depends on which of the soul dominant and influential in him. There is a self-interest oriented individual but not ignore the rights of others, such is the image of vegetable life. There is also a self-interest oriented individual and do not care with the rights of others, such is the image of animal soul. While the human rational soul is the individual with self-interest oriented also caring for the rights of others, as well as who considers various aspects related to himself and others that he is as part of the social life system.

The violence that appeared among the society can be caused by various factors, reasons, or backgrounds. Various problems in the society at any time can cause conflicts and even lead to a violence. The political background of the conflict often arises, as well as from the economic and social problems in general. The conflict and violence became hardened and powerful when packed in the religious issue. Because of such those phemomena, there is who say that religion in addition to unify mankind because of its nature as "adhesive power", also become divisive the people.

From there appeared skeptical attitude toward religion, that religion is often seen as something in double-faced. At one time the religion introduces peace, safety, unity, and brotherhood, but at other time it is seen as something that is potentially spreading conflict, even wars. The skepticism emerged as result of the partial interpretation and the use of religious symbols in these conflicts.

Instinctively, humans are known as desirous of establishing and keeping rules and regulations for a life together, so that called as homo juridicus because to live together there must be a rule which can cover the interests of each individual in society. Agreements in a common life must also be understood rationally, that every agreement has consequences which must be enforced not only with legal norms, but also with ethics, that is because man is also called homo ethicus.

There is a theory which states that human beings tend to be god woshiper, so he called a religious being (homo religiosus). And human religiosity seems not 
be limited by space and time. Although Auguste Comte, with his theory of Positivism, stated that the highest peak level of human civilization was in the positive phase or "positive stage". The thesis was unsuccessful and was criticized by various groups in the East and in the West itself, because the reality shows that however people still require religion and God.

There are several functions of religion for the people, as guidance (ershad) for worldly affairs and hereafter. It also serves as a social control, that means the religion also determine rules and norms of decency imposed upon social life in general, which is called akhlaq or morality, confirmed the good norms as rules and reject the bad ones. The other function of religion is as guards for the integrity and unity of mankind. Related to this case, the religion promotes the establishment of peace on earth.

If we refer to the Quran, we will find the existence of a conflict factor that emerged in the community. The Quran mentioned that the conflict factor actually originated from humans, because in his life there is a potential which always trys to pull him to deviate from the Devine values and norms. That was, among others, as a result of the dominance dimension or satanic and animal manner on the human soul.

There are many cases of conflict and even violence in society which packaged in a religious view, so it seemed that conflict and violence emerged from the religion. If we look at some of the statements of the Quran (Al-Rum, 30: 41), for example, "Corruption doth appear on land and sea because of (the evil) which men's hands have done", 11 we find that humans are the keys. The statement can be used as an argument that the spreader of conflict on earth, including in the middle real society, is the man himself. If it is associated to the religion, so the cause of the conflict is the adherents of religion and not the religion itself. The adherents of a religion are human, and in this case, conflicts cannot be separated from how the message of religion is interpreted by the adherents.

Maybe we find a conflict or violence caused by a trigger that was a small problem, but viewed as part of the religion. For example in towns, there is a quarrel because of the loudspeakers in place of worship, or drumming sounded to welcome the dawn time during Fasting month. Users of the device saw that what they do with the tools were as integral part of the religion, so it was considered as a "ritual", but the others saw not as such. Because there are differences in the assessment of interpersonal strife arose. Therefore, when the religious symbols highlighted then evolved into a collective emotion and enlarged to be violence.

The emergence of religious violence among the people is often caused by their ignorance or erroneous understanding to the religious messages. People who have not been properly educated (uneducated) are often manipulated by

11 Pickthall. The Meaning of the Quran. p. 427. 
those who are more educated (well educated) and cannot take choices in actions for the benefit of the educated person. Moreover, the religious symbolism (by the religious leaders) among the uneducated is something absolute and there is no compromise. So that whatever is recommended by the religious figures are the same significant as recommendation stated by the religion itself.

In the present times in Indonesia, complex issues often appear pattered as religious and looked in religious symbols. The violence also often appears with the religious symbolism. Until now, in the first decade of the 21st century, the unstable political situation, the religious symbols are "hard sell" like trade commodity. Even many persons considered as religious leaders are asked their advice (fatwa) to use the terminology of religion for particular problems and interests. For example, how a particular interest group raised terms in political jurisprudence (figh al-siyâsah) not appropriately to legitimize attitudes and actions simply to defend themselves or drop the rivals to gain support from the community who are actually religious people. Though the terms raised in the discourse of political figh here were limited in with certain criteria.

Another problem arises in accordance with the use of religious symbols is, the occurrence of collisions between the believers of a religion due to differences of approaches and interpretation, as well as the inclusion of elements of interest. That a group labeling as "hard-line" or "fundamentalist" for certain groups, and the label of "moderate" or "liberal" for the other groups, is unavoidable to make differences and when it not observed carefully may develop into a conflict. In this latter context, third party will come with specific interests easily and declare that religious symbols have no related way to the substance of the religion, because the substance of religion is the truth, and the highest truth is to God, while God is a substance that cannot be represented with symbols.

\section{Religious Language in the Contemporary Issues}

Normatively all religions teach harmony and peace. When there is a conflict or discord in a group of religious community, it must be found the roots of the problem. The religious teaching never becomes a trigger for the social conflict. It was shown in the history that the conflicts and wars were not caused by the Holy Scripture.

In the contemporary era, violence and terror in the name of religion often appear due to a misunderstanding of religion, or because religion no longer be something that binds a person's life. In this case the religion is considered to have lost its authority.

If we remember the attack on The World Trade Center in September 11, 2001, since then Islam became main theme of many public forums. It has been caused by the opinion that the tragedy was based on the religious political reasons. The attack object was the symbol of secular economic and political power. Many experts talked about Islam as a radical movement. Many others 
wanted to know more about this religion, so they made or attended conferences in many campuses or other places on the religion such as interfaith dialogue forums. Here, Islam misunderstood as religion of terror and violence. Many of academicians saw that the tragedy had political background and not religious one, and they tried to explain the impossibility of attack on the huge building except with military powers.

When social conflicts occur, religion also often involved to strengthen those who involved in the conflict. For example, when the ethnical conflict occured in Indonesia a few years ago between Chinese people and indigenous people, the conflict became stronger due to the religious association which Chinese are Christians and the indigenous are Muslims. Finally, the conflict nuanced as a religious clash between Christianity and Islam. So also is the case in Burma between the dominant tribe and tribe of Rohingya, where the dominant are Buddhists and Rohingya are Muslims.

At this time, a symbol of religion is a very interesting for the world. In the reports of mass media, there is an emergence of the biggest transnational political movement, which called the Islamic State of Iraq and Syria (ISIS) or the Islamic State of Iraq and the Levant (ISIL). Related to the movement people may ask about their existence: did the fighters of this movement really act in the name of Islam? The first thing we need is to listen to the fighters themselves. They mentioned that their main motive is to defend Islam from the violence acted by the United States and its allies. Here, it's clear that their movement is political. This movement promotes religious symbols, such as khilâfah (caliphate), dawlah islâmiyah (Islamic state), jihad (holy war), and other terminologies of religious teaching. So that, the world assume that ISIS appears to represent Islam, because all various attributes attached to the movement and its activists are patterned Islam.

\section{Epilogue}

The religious symbolism is often necessary in a lot of interest for the society. Moreover, many of the people become more excited and passionate when religious symbols displayed, although the spirit and passion they might not show up when they see the religious teachings.

In the social experience, many who think that religious symbolism is important, to show identity, or a mere formality. To understand the urgency of religious symbolism should be seen in a comprehensive and contextual perspective.

There is the recommended religious symbolism, for goodness and interests, however there is a symbol that is not recommended even prohibited, the use of symbols that are not appropriate and targeted, or improper purpose. Especially if deliberately used to injustice against other parties. 
The spirit of religion in the collective life is to create the beneficiaries for the adherents of the religion, even the Quran explicitly states that the presence of Islam as rahmatan lil-'âlamin, the reflection of God's bless for all the inhabitants of this universe.

\section{References:}

Abrahamian. 1989. Radical Islam: The Iranian Mojahedin. London: Tauris.

Albanese, Catherine. 2007. America Religions \& Religion. Santa Barbara: Thomson.

Al-Maktaba al-Shamela, version 3.48. http:/ / www.shamela.ws

Daya, Burhanuddin. 2004. Religion of Dialogue. Yogyakarta: Mataram-Minang Lintas Budaya.

Hitti, Philip. 1970. History of the Arabs. London: Macmillan.

Mughni, Syafiq. 2011. Behind the Symbols: Understanding Religious Message with the Spirit of Progress. Surabaya: Hikmah Press.

Pickthall, Muhammad. 1980. The Meaning of the Glorious Quran: Text and Explanatory Translation. Karachi: Idaratul Quran.

PWM Jatim. 2002. Muhammadiyah the Victim of Political Violence. Surabaya: PW Muhammadiyah Jatim.

Sjadzali, Munawir. 2000. Islam and Constitutions. Jakarta: UI-Press.

Syahid, Achmad. 2002. Lanaguage, Education, and Religion. Jakarta: Logos. 